\title{
CONTEMPORARY TRENDS IN THE PUBLIC SECTOR PROJECT MANAGEMENT
}

\author{
Vladimir Obradović \\ Faculty of Organizational Sciences, University of Belgrade, Serbia
}

\begin{abstract}
Project management as a discipline heavily originated from the public sector and has widely spread in the for-profit companies, non-governmental and civil society organizations. Nowadays it is getting back to the public sector trying to make it more efficient and even effective. The European Union, United States, Russia and other countries are introducing new project based methodologies as a mandatory or recommended methodology in the governments and governmental bodies. This paper aims to, based mainly on a desk research, present latest trends in afore mentioned trends. The idea behind is to show approaches that are being introduced, but also to advocate and promote further development of public sector project management methodologies in the countries worldwide.
\end{abstract}

Key words: Pubic sector, Project management, European Union, Russian Federation, Croatia, Serbia.

\section{INTRODUCTION}

The approaches that are to be presented in this paper have been taken form the relevant literature but also gained from the interviews and general public sources. Major of the findings has been presented at the 22 . International project management conference and has provoked substantial interest from the audience, hence the need to publish it in a journal article to make it more visible to the larger audience (Obradović, 2018). Project management is a discipline which emerged from the public sector (Jovanović, 2012) within projects such as Polaris and Apollo (Lee, Moeller, \& Digman, 1982). Howeer, it reached its full expansion in the private sector where its initial focus was directed towards the iron triangle (Rani, 2014) as a measure of the success of the project. The definition of success has changed over time (Hope, \& Ebbesen, 2013) and was becoming increasingly complex so that success factors also became more numerous (Todorović, Petrović, Mihić, Obradović, \& Bushuyev, 2015). In various sectors it was difficult to "defeat" traditional occupations (Obradović, Jovanović, Đorđević, Berić, \& Jovanović, 2012) and point out the need for a project manager as a profession (Semolič, Jovanović, Kovačev, \& Obradović, 2008). A professional project manager became demanded and valued over time, mostly in the profit sector, where it had been proved that it is necessary to have individuals with adequate competences to ensure the success of the project (Bogojević, 2017). This profession is especially marked in contemporary demographic trends and deserves additional attention, especially in the area of education and training (Obradović, Mitrović, \& Pavićević, 2017).

Project management as a discipline has slowly been moving or returning to the public sector in the past few years, introducing different methodologies and approaches aimed at improving the effectiveness and efficiency of public policies through project management. It is spread in some areas like infrastructure project and growing in some other areas like healthcare (Obradović, et al., 2012).

The paper will present some of the most important examples, primarily because they refer to the strongest global economies. In addition, there will be a review of other positive examples from Europe. In order to comprehensively consider the problems of project management in the public sector, this paper will present and analyze the situation of this area in the Republic of Serbia. 


\section{THE UNITED STATES OF AMERICA}

The former President of the United States, Barack Obama, after it was passed in Congress, signed a law which introduces project management as a binding methodology at the federal government level: Program Management Improvement and Accountability Act of 2015 - PMIAA (114th Congress (20152016), 2016) .

The Act reforms federal program management policy through four initiatives:

- Creating formal jobs and careers for program managers in the federal government;

- Developing a standardized program management policy throughout the federal government;

- Recognizing the key role of executive sponsorship and engagement of senior executives in federal agencies to be responsible for program management policy and strategy,

- Knowledge-sharing regarding successful approaches to program management via an interagency council on program management.

The Act envisages a whole series of changes in the way the federal government operates. Senior officials (for example, deputy director of management) are assigned responsibilities related to project management and programs:

- the adoption of standards, policies and guidelines for project management;

- overseeing the introduction of project management based on the abovementioned standards, policies and guides;

- maintenance of the Program Management Policy Council;

- the introduction of specific standards and policies for executive agencies consistent with broadly accepted standards for planning and executing programs and projects;

- cooperation with the private sector in identifying best practices in program and project management, with the aim of improving the federal program and project management;
- analysis of project portfolio in order to reduce risk, improve quality and increase effectiveness;

- adopting a five-year strategic plan for managing programs and projects.

Furthermore, all executive directors are required to appoint a senior management to improve program management - Program Management Improvement Officer, who are tasked with developing a strategy to enhance the role of program and project managers through:

- trainings,

- mentorship,

- career advancement and possibilities,

- recruiting and keeping highly qualified individuals.

The Human Resources Department at the federal level should develop a regulation which would:

- identify key skills and competencies required for program and project managers in federal agencies;

- establish a new set of job positions for program and project managers in federal agencies;

- establish a career path for program and project managers in federal agencies.

Based on the aforementioned, it can be concluded that the United States is determined to introduce project management at the federal level as a methodology which will improve the efficiency of public administration. There is a strong tendency to develop the profession of the project manager.

It remains to be seen to which extent the developed methodology will be based on traditional approaches, primarily PMI, and to which extent it will incorporate the agile philosophy.

\section{EUROPEAN UNION}

For a long time, the European Union relied on a project cycle management model, the socalled Project Cycle Management - PCM. This approach (cannot be called a methodology) has not been sufficiently elaborated and did not provide enough concrete responses to the challenges in planning and monitoring various projects funded from the EU funds. As a result, the European Commission decided to develop 
a new methodology and as a result of this initiative, the Open Project Management Methodology - OpenPM2was created.

The aforementioned methodology is ideal for projects related to the public sector, EU programs and grants. By its very nature, it represents a hybrid of existing methodologies, combining traditional and agile principles.

The Open Project Management Methodology draws its high level of usefulness from a great degree of dilution and applicability. Namely, a whole set of products and mechanisms were developed in order to facilitate the use of $P M 2$. As project managers in the public sector are often not educated or not educated enough for this area, ready to use tools and instructions come in very useful

OpenPM ${ }^{2}$ offers:

- $\quad \mathrm{PM}^{2}$ Guide

- $\mathrm{PM}^{2}$ templates

- $\mathrm{PM}^{2}$ on-line resources (wiki)

- Project Support Network - a network/community of $\mathrm{PM}^{2}$ users which support each other in developing and implementing the methodology in their organizations and projects.

In addition to the above-mentioned methodologies, local Project Support Offices will soon be established as part of the OpenPM $^{2}$ Project Support Network, and additional PM2 publications will be issued. OpenPM2 was translated into most of the official EU languages and, according to the author's knowledge, will soon be translated into Serbian as well.

It is also important to emphasize that $\mathrm{OpenPM}^{2}$ introduces a number of roles in project management: the appropriate governing body, project owner, business manager, business implementation group, project management board, decision maker, project manager, senior project team and project support team.

Although this set of roles has its solid foundation in the methodology, which divides the project cycle into the initiation, planning, implementation and closure of the project, bearing in mind the previous experience in the functioning of the European Union administration, it remains concerned that this controlling device does not become overly cumbersome and bureaucratic. Also, in the author's opinion, the methodology does not put enough emphasis on the project profession, but rather on the standardization of project processes.

\section{RUSSIAN FEDERATION}

The Russian Federation has also recognized the importance of the methodology of project management in the state administration and the public sector in general. Accordingly, within the Analytical Center of the Government of the Russian Federation which provides analytical and expert support there are three departments dealing with project management, but the bearer of the methodology is the Public Sector Management Department.

This department conducts research on the effective implementation of the project and program management in the public sector. Furthermore, the department has the role of providing expert and methodological support to public sector organizations.

Special mention should also be made of the Olimp project, which is being implemented since 2014 and represents a unique competition in project management. Each year, hundreds of participants take part in this prestigious project to determine who is the best project manager and which public sector projects had been the most effective and efficient in the past year.

The Public Sector Management Department puts special attention to the development of the project manager as a profession. As the growth of this profession is huge, it is necessary to provide a certain level of standardization of the quality of professionals in this field. Although recognized as adequate, the PMI, IPMA and PRINCE2 systems are not the best solution for the mass certification system in Russia, primarily because of the price, so a national four-tier model certification project was developed which represents an important step in the further development of project management.

\section{OTHER EXAMPLES}

Regarding the region, the most positive example of recognizing and strengthening 
project management and the project management profession can be found in Croatia, which legally prescribed the obligation of certification of project managers in order to improve project management. In July 2015, the Law on Business and Spatial Planning and Construction Act entered into force, obliging investors to appoint a project manager. In accordance with the abovementioned law, the project manager must, inter alia, have an internationally recognized project management certificate (e.g. PMI or IPMA).

The provisions of this law have triggered a significant increase in the certification of project managers, and therefore in the improvement of the methodology, which ultimately aims at more efficient and effective project management.

Portugal has established an operational Center for Excellence in Project and Portfolio Management, which is a service for public sector organizations within the framework of joint government services. Besides the methodology, the Center also provides software platform SaaS (Software as a Service), which aims to provide support in the application of the standardized methodology.

This Center is focused into three key areas:

- strategic harmonization of projects,

- optimization of project implementation, and

- maximizing benefits

The Center supports both the development of methodologies for project and portfolio management, as well as the development of the project manager as a profession. They evaluate the quality of their work externally by applying to professional project management organizations such as IPMA and PMI, nominating their projects and project managers for different awards and recognitions. In this way they confirm the results of their work.

In addition to the abovementioned examples of Croatia and Portugal, many other countries are working intensively on introducing project management into public administration and the public sector (e.g. Poland).
At the moment, there is no body (organizational unit) in Serbia which would be responsible for the development and improvement of the methodology. Furthermore, although the Law on Budget System stipulates that annual financial plans are made on the basis of defined programs and projects, there is no adopted methodology that would be binding or at least recommended for users of budgetary funds - neither traditional nor agile. Within certain ministries, there are units which do have guidelines for project management in their title, but this is mostly related to projects financed by the EU and other donor funds. In addition, there are no professionally defined requirements for managers of such units (e.g. IPMA Level $A \circledR$ or PMI PgMP $\left.{ }^{\circledR}\right)$, nor for employees in these units (e.g. IPMA Level D / C® or PMI PMP ${ }^{\circledR}$ ). Certification of project managers is vital for the success of the projects as long as it is adequately standardized (Toljaga-Nikolić, Obradović, \& Mihić, 2011). As previously mentioned, there is no methodology that would be unified and standardized for different parts of the same government. Therefore, any improvement in this area cannot be expected in the near future.

\section{CONCLUSION}

A great number of countries around the world, across all continents, established or are in the process of establishing methodologies for project management in the public sector: the United States, the EU, the Russian Federation, Portugal, Croatia, Poland, etc. The States mostly develop their own methodologies by relying more or less on external professional organizations such as IPMA and PMI. This tendency is primarily aimed at improving the efficiency of the work of the public administration by developing a standardized approach in management, but also through developing the profession of a project manager. Time will show to what extent these improvements will be achieved.

There is currently no standardized approach to project management in the public sector level of Serbia, and, to the best of author's knowledge, there is no initiative to develop something like that. 
However, having in mind widely spread methodologies around the world, one could expect that this trend will continue and that more and more governments will adopt project based approaches, hopefully build on already tested concepts, that would enhance the efficiency and effectiveness of public sector management.

\section{Acknowledgments}

The paper shows the results of the research made within the OI 179081 project funded by the Ministry of Education, Science and Technological Development of the Republic of Serbia.

\section{REFERENCE}

114th Congress (2015-2016). (2016, December 12). S.1550 - Program Management Accountability Act. USA.

Bogojević, P. (2017, December). Comparative Analysis of Agile Methods For Managing Software Projects. European Project Management Journal, 7(1).

Hope, A., \& Ebbesen, J. B. (2013). Reimagining the Iron Triangle: Embedding Sustainability into Project Constraints. Retrieved 11 22, 2018, from http://nrl.northumbria.ac.uk/11311

Jovanović, P. (2012). Upravljanje projektom (deseto ed.). Beograd: Visoka škola za projektni menadžment.

Lee, S. M., Moeller, G. L., \& Digman, L. A. (1982). Project/Venture Management. Retrieved $11 \quad 22$, 2018, from https://link.springer.com/chapter/10.1007 1978-94-009-8171-3_2

Obradović, V. (2018). Upravljanje projektima u javnom sektoru: agilno ili tradicionalno.
Poslovna agilnost $i$ agilno upravljanje projektima (pp. 20-26). Beograd: Udruženje za upravljanje projektima Srbije.

Obradović, V., Jovanović, P., Đorđević, N., Berić, I., \& Jovanović, F. (2012). Using project management as a way to excellence in healthcare. HealthMED, 6(6), pp. 2100-2107.

Obradović, V., Mitrović, Z., \& Pavićević, M. (2017). Millennials vs. Baby Boomers in project management: Education and training gap. Computer Sciences and Information Technologies (CSIT), 2, pp. 22-29. doi:10.1109/STCCSIT.2017.8099422

Rani, H. A. (2014). The iron triangle as the triple constraints in project management. Retrieved 11 22, 2018, from http://ejournal.unmuha.ac.id/index.php/ts ipil/article/view/222

Semolič, B., Jovanović, P., Kovačev, S., \& Obradović, V. (2008). Improving repair management of bucket wheel excavator SRs1200 by application of project management concept. Strojniski vestnikJournal of Mechanical Engineering, 54(6), pp. 398-412.

Todorović, M., Petrović, D., Mihić, M., Obradović, V., \& Bushuyev, S. (2015). Project success analysis framework: A knowledge-based approach in project management. International Journal of Project Management, 33(4), pp. 772-783. doi:DOI: 10.1016/j.ijproman.2014.10.009

Toljaga-Nikolić, D., Obradović, V., \& Mihić, M. (2011). Certification of Project Managers Based on IPMA and PMI Models Through Conforming to ISO 17024:2003. Management(59), 45-53. 